\title{
Penyuluhan Customer Service dan Positioning Product pada PT. Barus Indah di Kota Medan
}

\author{
Aulia Arief Nasution' ${ }^{1}$ dan Rizki Fillhayati Rambe ${ }^{2}$ \\ ${ }^{1}$ Manajemen Perkantoran Universitas Harapan Medan, Jalan Imam Bonjol No. 35, Medan, Indonesia, 20152 \\ ${ }^{2}$ Akuntansi Universitas Harapan Medan, Jalan Imam Bonjol No. 35, Medan, Indonesia, 20152
}

Correspondence: fillhayati@gmail.com

Received: 30 Juni 2021 - Revised: 01 Agustus 2021 - Accepted: 16 Agustus 2021

\begin{abstract}
Abstrak. Transportasi merupakan sarana yang penting dalam kelangsungan roda perekonomian. Kebutuhan akan transportasi semakin meningkat seiring dengan meningkatnya pertumbuhan penduduk di Indonesia. Untuk di kota medan khususnya, sarana transportasi antar kota jenis travel masih menjadi pilihan karena memiliki keunggulan jika dibandingkan dengan transportasi darat lainnya. Semakin ketatnya persaingan bisnis yang ada, terutama persaingan yang berasal dari perusahaan sejenis, membuat perusahaan semakin dituntut lebih ekstra dalam menarik pelanggan. Sehingga perusahaan dalam menerapkan konsep pemasaran perlu mencermati faktor yang mempengaruhi keputusan pembeli dalam usaha pemasaran jasanya. Selain itu perusahaan harus mampu memelihara konsumen pasca-penggunaan jasanya. Mitra kegiatan pengabdian masyarakat ini adalah PT. Barus Indah. PT. Barus Indah merupakan salah satu perusahaan yang bergerak dalam bidang transportasi di Kota Medan. Permasalahan yang dihadapi oleh mitra yaitu masih belum menyadari mengenai pentingnya pelayanan terhadap pelanggan, dan cara memosisikan jasa mereka dihadapan pelanggan. Melalui kegiatan Pengabdian kepada Masyarakat ini, PT. Barus Indah akan diberikan bekal pengetahuan mengenai Penguatan Sumber Daya Manusia dengan Customer Service, dan memposisikan jasa mereka dihadapan konsumen dengan Positioning Product, sehingga diharapkan dapat meningkatkan pendapatan perusahaan dan lebih dikenal di masyakarat, walaupun persaingan usaha sejenis semakin bertambah. Pelaksanaan pelatihan di PT. Barus Indah berjalan sesuai dengan harapan. Banyaknya pertanyaan saat pelatihan menunjukkan bahwa peserta mampu memahami materi pelatihan customer service maupun positioning produk. Dampak dari kegiatan pengabdian kepada masyarakat ini adalah PT. Barus Indah lebih memahami berbagai cara yang dapat dilakukan untuk dapat bersaing dengan perusahaan sejenis dan memenangkan hati pelanggan.
\end{abstract}

Kata kunci: Customer service, positioning produk, jasa, transportasi, supir.

Citation Format: Nasution, A.A., \& Rambe, R.F (2021). Penyuluhan Customer Service dan Positioning Product pada PT. Barus Indah di Kota Medan. Prosiding Seminar Nasional Abdimas Ma Chung (SENAM), 154-163. 


\section{PENDAHULUAN}

Transportasi merupakan sarana yang penting dalam kelangsungan roda perekonomian. Kebutuhan akan transportasi semakin meningkat seiring dengan meningkatnya pertumbuhan penduduk di Indonesia. Transportasi sangat dibutuhkan masyarakat untuk mobilitas penumpang maupun barang yang digunakan untuk menunjang kegiatan prekonomian. Perekonomian yang semakin berkembang membuat mobilitas yang tinggi, sehingga masyarakat akan semakin jeli dalam memilih sarana transportasi yang akan digunakan. Hal tersebut yang menjadikan adanya persaingan dalam bisnis penyedia jasa transportasi. Persaingan bisnis semakin ketat sehingga menuntut perusahaan penyedia jasa transportasi melakukan.

Di Indonesia, terdapat berbagai jenis moda transportasi baik darat, laut, maupun udara. Namun, moda transportasi darat masih menjadi primadona bagi beberapa masyarakat. Terdapat berbagai alternative penggunaan sarana transportasi darat seperti bus, travel, mobil angkutan umum, taksi maupun kereta api.

Untuk di kota medan khususnya, sarana transportasi antar kota jenis travel masih menjadi pilihan karena memiliki keunggulan jika dibandingkan dengan transportasi darat lainnya. Salah satu keunggulan yang dimilikinya yaitu penumpang tidak perlu repot untuk mendatangi loket sebelum berangkat. Perusahaan travel memberi layanan penjemputan penumpang. Penumpang hanya perlu memastikan alamat penjemputan dan alamat pengantaran. Pelayanan ini tidak dibebankan tambahan biaya.

Semakin ketatnya persaingan bisnis yang ada, terutama persaingan yang berasal dari perusahaan sejenis, membuat perusahaan semakin dituntut lebih ekstra dalam menarik pelanggan. Sehingga perusahaan dalam menerapkan konsep pemasaran perlu mencermati faktor yang mempengaruhi keputusan pembeli dalam usaha pemasaran jasanya. Selain itu perusahaan harus mampu memelihara konsumen pasca penggunaan jasanya. Hal ini penting dikarenakan dalam konsep, salah satu cara untuk mencapai tujuan perusahaan adalah dengan mengetahui apa kebutuhan dan keinginan konsumen atau pasar sasran serta memberikan kepuasan yang diharapkan secara lebih efektif dan efisien dibandingkan para pesaing (Kotler dan Keller, 2012). 


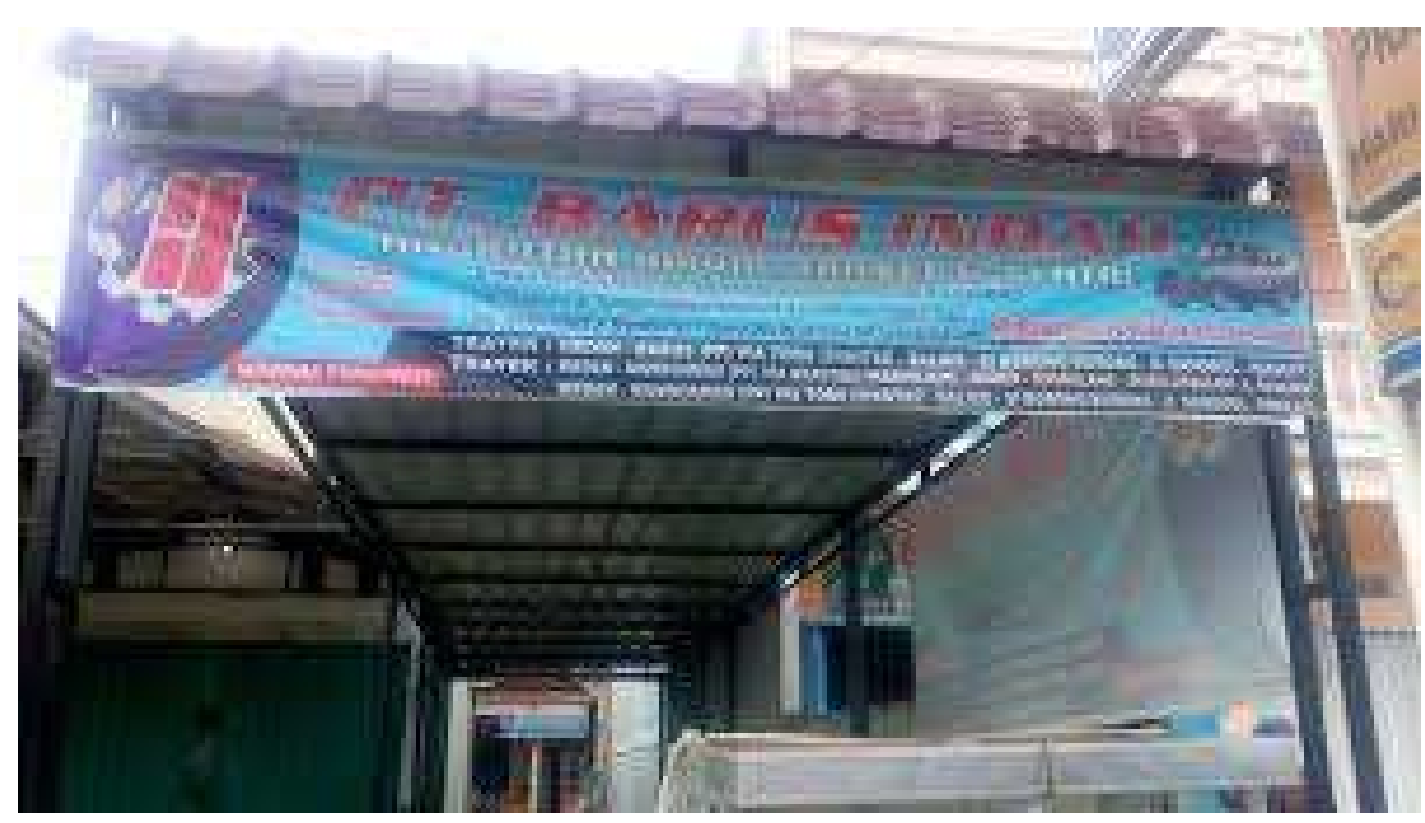

Gambar 1. PT. Barus Indah di Medan, Sumatera Utara

Mitra kegiatan pengabdian masyarakat ini adalah PT. Barus Indah. PT. Barus Indah merupakan salah satu perusahaan yang bergerak dalam bidang transportasi di kota medan. Rute yang diambil adalah dari Medan ke Barus, dan sebaliknya. Selain mengantar penumpang, PT. Barus Indah juga melayani pengiriman barang. PT. Barus Indah beralamat di Jalan Raya Menteng Ujung No. 9A, Medan. (Gambar 1 dan Gambar 2)

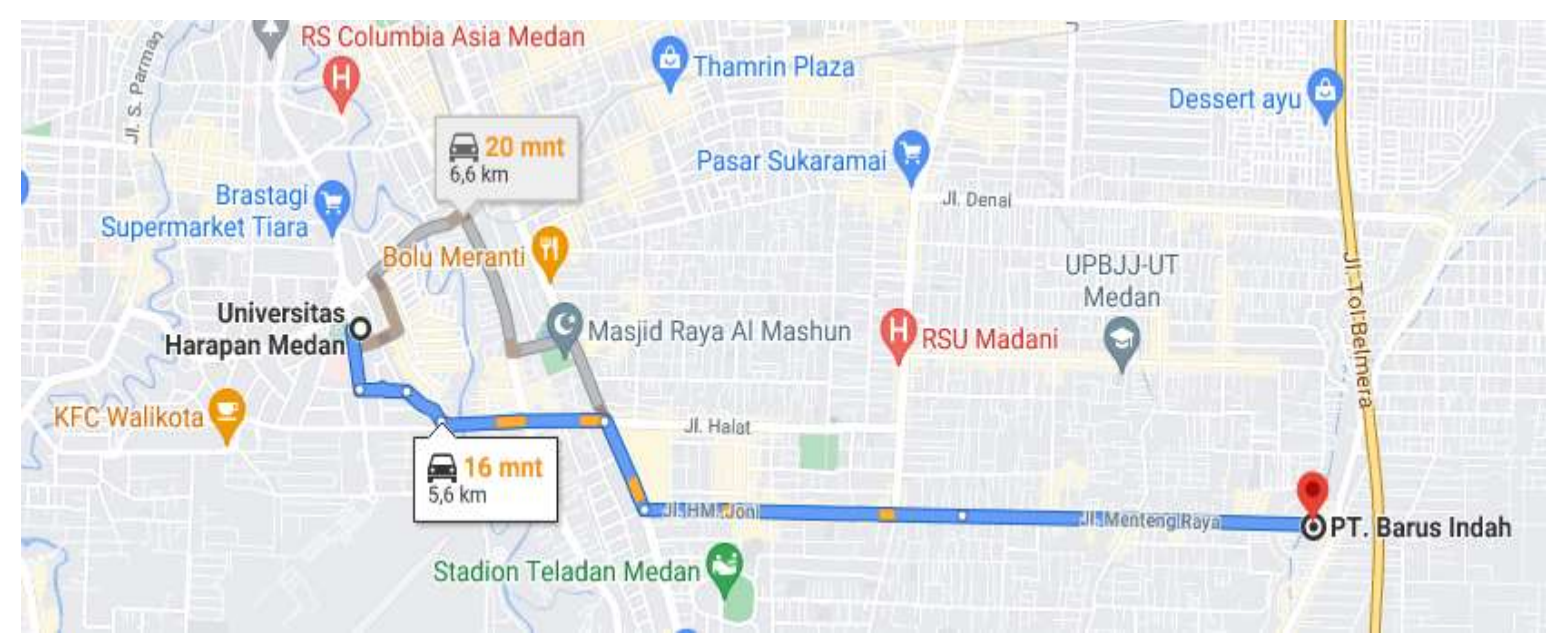

Gambar 2. Peta PT. Barus Indah di Medan, Sumatera Utara

Kepuasan pelanggan menjadi kunci sukses bagi perusahaan untuk dapat berkembang dan bertahan hidup. Untuk meningkatkan kepuasan pelanggan maka pelayanan harus ditingkatkan. Hal ini mendorong munculnya kebutuhan untuk melakukan pelatihan singkat guna memahami strategi penjualan jasa travel, yaitu dengan penguatan Sumber Daya 
Manusia dan memposisikan jasa meraka dihadapan konsumen. Diharapkan melalui pelatihan singkat tersebut, pangsa pasar menjadi semakin luas dan pendapatan semakin meningkat.

\section{MASALAH}

Permasalahan yang dihadapi oleh mitra yaitu masih belum menyadari mengenai pentingnya pelayanan terhadap pelanggan, dan cara memposisikan jasa mereka dihadapan pelanggan. Melalui kegiatan Pengabdian kepada Masyarakat ini, PT. Barus Indah akan diberikan bekal pengetahuan mengenai Penguatan Sumber Daya Manusia dengan Customer Service, dan memposisikan jasa mereka dihadapan konsumen dengan Positioning Product, sehingga diharapkan dapat meningkatkan pendapatan perusahaan dan lebih dikenal di masyakarat, walaupun persaingan usaha sejenis semakin bertambah.

\section{METODE PELAKSANAAN}

Kegiatan Pengabdian kepada Masyarakat ini dilakukan menggunakan metode pelatihan singkat dan evaluatif. Adapun penjelasan masing-masing metode tersebut adalah sebagai berikut:

1. Pelatihan singkat, yaitu ceramah atau seminar mengenai penguatan SDM dan positioning produk.

2. Evaluatif, yaitu tahapan untuk mengetahui tingkat pencapaian sasaran dari kegiatan pelatihan yang telah dilaksanakan melalui kuesioner yang dibagikan kepada para peserta pelatihan

Pelatihan dilaksanakan pada hari Kamis, Tanggal 4 Agustus 2020 di PT. Barus Indah, Medan. Berikut adalah tabel berupa metode yang disampaikan kepada peserta.

Tabel 1. Metode Pelaksanaan

\begin{tabular}{clll}
\hline No. & Materi Pelatihan & Alokasi Waktu & \multicolumn{1}{c}{ Metode } \\
\hline \multirow{2}{*}{1} & Customer Service & 2 Jam & 1. Ceramah \\
& & 2. Diskusi/Tanya Jawab \\
2 & Positioning Product & 1 Jam & 1. Ceramah \\
& & 2. Diskusi/Tanya Jawab \\
\hline
\end{tabular}

\section{HASIL DAN PEMBAHASAN}

Pelaksanaan kegiatan pengabdian kepada masyarakat pada PT. Barus Indah yang 
dilaksanakan disambut dengan baik oleh pihak manajemen PT. Barus Indah. Walaupun kehadiran peserta, khususnya sopir PT. Barus Indah tidak sebanyak dengan undangan yang telah disebar ke sopir PT. Barus Indah. Mengingat sangat sulit bagi mereka untuk mencari waktu senggang mengikuti kegiatan pengabdian kepada masyakat, dikarenakan sebagian sedang dalam perjalanan mengantarkan penumpang ke Barus, Tapanuli Tengah. Akan tetapi melalui perwakilan beberapa orang sopir PT. Barus Indah yang hadir sudah bisa mewakili sopir lainnya yang ada di PT. Barus Indah, Medan. Yaitu dari 11 (sebelas) orang yang diundang, yang dapat menghadiri kegiatan sebanyak 8 (delapan) orang.

\section{Pelatihan}

Pada Tahap pelaksanaan yakni Tim melakukan kegiatan penyuluhan dengan metode ceramah dan Tanya jawab. Pada pelaksanaan kegiatan ini Tim memberikan materi tentang Customer Service dan Positioning Produk kepada peserta.

\section{Pelatihan Customer Service}

Menurut Lupiyoadi (2001) perbedaan utama antara perusahaan penghasil produk berupa barang dengan perusahaan penghasil jasa adalah pada pemasarannya, di mana jasa lebih dituntut memberikan kualitas yang optimal dari customer service. Costumer Service pada pemasaran jasa lebih dilihat sebagai outcome dari kegiatan distribusi dan logistik, dimana pelayanan diberikan kepada konsumen untuk mencapai kepuasan. Costumer service meliputi berbagai aktivitas di seluruh area bisnis yang berusaha mengkombinasikan antara penjualan jasa untuk memenuhi kepuasan konsumen mulai dari pemesanan, pemrosesan, hingga pemberian hasil jasa melalui komunikasi untuk mempererat kerja sama dengan konsumen. Costumer Service bukan sekedar maksud melayani namun merupakan upaya untuk membangun suatu kerja sama jangka panjang dengan prinsip saling menguntungkan. Proses ini sudah mulai sebelum terjadi transaksi hingga tahap evaluasi setelah transaksi. Costumer Service yang baik adalah bagaimana mengerti keinginan konsumen dan senantiasa memberikan nilai tambah di mata konsumen. Menurut Lupiyoadi (2001) untuk mencapai kinerja yang tinggi dalam Costumer Service, manajemen perusahaan jasa juga harus menyiapkan SDM melalui training tentang bagaimana menghadapi permintaan konsumen, mengadakan komunikasi personal yang memberikan kesempatan bekerja sama dengan kualitas lebih baik.

Setelah dilakukan pelatihan diharapkan peserta memiliki sikap dan kemampuan yang mumpuni untuk melaksanakan pelayanan kepada pihak internal dan eksternal. Selain 
itu dapat komunikasi dengan baik dan lancar.

Adapun materi yang disampaikan dalam pelatihan customer service ini adalah : (1) Kesadaran berprofesi melalui teori pelayanan prima dan attitude driver; (2) Etika dalam mengendarai mobil dan pelayanan terhadap penumpang; (3) Disiplin dan sadar akan rambu lalu lintas; (4) Etika dalam bekerja; (5) Telephone contacs; (6) Kesadaran profesi; dan (7) Urutan pelayanan.

Tabel 2. Hasil Nilai Pre-test dan Post-test Pelatihan Customer Service

\begin{tabular}{clcc}
\hline No. & \multicolumn{1}{c}{ Materi } & Pre-test & Post-test \\
\hline 1 & $\begin{array}{l}\text { Kesadaran berprofesi melalui teori } \\
\text { pelayanan prima dan attitude driver }\end{array}$ & $4(50 \%)$ & $7(88 \%)$ \\
\hline 2 & $\begin{array}{l}\text { Etika dalam mengendarai mobil dan } \\
\text { pelayanan terhadap penumpang }\end{array}$ & $5(63 \%)$ & $8(100 \%)$ \\
\hline 3 & Disiplin dan sadar akan rambu lalu lintas & $3(38 \%)$ & $8(100 \%)$ \\
\hline 4 & Etika dalam bekerja & $4(50 \%)$ & $8(100 \%)$ \\
\hline 5 & Telephone contacs & $4(50 \%)$ & $6(75 \%)$ \\
\hline 6 & Kesadaran profesi & $5(63 \%)$ & $7(88 \%)$ \\
\hline 7 & Urutan pelayanan & $4(50 \%)$ & $6(75 \%)$ \\
\hline
\end{tabular}

Dari Tabel 2 dapat dilihat bahwa setiap dari 7 poin yang dijelaskan, terjadi peningkatan pemahaman dari sebelum diberikan materi tentang Customer Service dan setelah diberikan materi Customer Service. Untuk bagian Kesadaran berprofesi melalui teori pelayanan prima dan attitude driver, terjadi peningkatan pemahaman yaitu dari $50 \%$ menjadi 88\%. Untuk bagian Etika dalam mengendarai mobil dan pelayanan terhadap penumpang, terjadi peningkatan pemahaman yaitu dari 63\% menjadi $100 \%$. Selanjutnya, untuk bagian Disiplin dan sadar akan rambu lalu lintas juga terjadi peningkatan yaitu dari 38\% menjadi 100\%. Bagian Etika dalam bekerja meningkat dari 50\% menjadi 100\%. Bagian Telephone contacs meningkat dari 50\% menjadi 75\%. Untuk bagian Kesadaran profesi meningkat dari $63 \%$ menjadi $88 \%$. dan terakhir untuk bagian Urutan pelayanan meningkat dari 50\% menjadi $75 \%$.

Peningkatan ini mengindikasikan bahwa telah terjadi penambahan pengetahuan dikalangan peserta pelatihan. Tentu saja, diharapkan akan berpengaruh dalam melaksanakan aktivitasnya dan ketika berhubungan dengan pelanggan. Sehingga perusahaan menjadi lebih baik lagi dihadapan pelanggannya. 


\section{Positioning Produk}

Materi yang kedua yakni Positioning produk dalam hal ini Kendaraan PT. Barus Indah yang dimiliki beserta yang ada di dalamnya sehingga menjadi suatu kemasan yang menarik. Menurut Tjiptono dan Chandra (2016) Positioning pasar yaitu proses menciptakan persepsi unik dan unggul dalam benak konsumen. Langkah diferensiasi dan positioning terdiri dari 3 tahap yaitu : (1) Mengidentifikasi sekumpulan keunggulan kompetitif yang berbeda di mana untuk membangun posisi; (2) Memilih keunggulan kompetitif yang tepat; dan (3) Memilih strategi positioning secara keseluruhan (Widjaya, 2017). Positioning poduk dianggap penting karena dapat mempengaruhi keputusan pembelian pelanggan, baik pembelian produk maupun jasa, seperti hasil penelitian yang dilakukan oleh Mauliansyah (2017) dan Butar-Butar (2018).

Positioning Product dalam hal ini kendaraan yang digunakan yakni PT. Barus Indah tentu saja harus dijaga, dirawat/diperhatikan untuk maintenance-nya sehingga tetap terawat, baik sehingga tidak akan kalah bersaing dengan travel sejenisnya. Maka dari itu, dibuatkan Form Checklist Inspeksi Harian Kendaraan PT. Barus Indah. Dapat dilihat pada Gambar 2. 


\begin{tabular}{|c|c|c|c|}
\hline \multicolumn{4}{|c|}{$\begin{array}{c}\text { CHECKLGT INSPEXSI HAFIAN KENDARAAN } \\
\text { PT BAAUS INDAH }\end{array}$} \\
\hline \multicolumn{4}{|c|}{$\begin{array}{l}\text { DATA KENDARAAN } \\
\text { IENOS/MERX: } \\
\text { NO. POL: } \\
\text { TANGGAL S LAM INSPEESSI: }\end{array}$} \\
\hline No & PEMERUIKSACAN & CHECKLST & KETERANGAN \\
\hline 1 & DU MESIN & & \\
\hline 2 & OU REM & & \\
\hline 3 & KOPLING & & \\
\hline 4 & AIR RADUTOF & & \\
\hline 5 & ALA. AKi & & \\
\hline$E$ & KAREURATOR. & & \\
\hline 7 & AC. & & \\
\hline 8 & WIFER & & \\
\hline 9 & TAUI KIFAS & & \\
\hline 10 & LAMPUR EESAR & & \\
\hline II & LAMPU KECIL & & \\
\hline 12. & LAMPU SEIN & & \\
\hline 13 & SURAT KE NDARAAM & & \\
\hline 14 & PEMANAASAN & & \\
\hline 15. & TEXANAW ANGIN BAAN & & \\
\hline 16 & BSM & & \\
\hline 17 & KEHEELSIHASY/CUCI & & \\
\hline 18 & DONGKAAK & & \\
\hline I9 & KOTAK P3K & & \\
\hline 20 & SEGITIGA PENGAMAN & & \\
\hline 21 & EAN SERAF & & \\
\hline & & $\begin{array}{l}\text { MENGETAHL } \\
\text { KOORDINAT: }\end{array}$ & DE KENDARAAN \\
\hline & & I & I \\
\hline
\end{tabular}

Gambar 2. Form Checklist Inspeksi Harian Kendaraan PT. Barus Indah

Form Checklist Inspeksi Harian Kendaraan PT. Barus Indah didesain untuk menjaga kualitas kendaraan perusahaan. Sehingga dapat dipastikan bahwa hanya kendaraan yang sudah melalui Inspeksi Harian yang bisa melanjutkan perjalanannya.

\section{Evaluasi}

Pada kegiatan Pengabdian kepada Masyarakat ini, pelatihan diakhiri dengan melakukan evaluasi kegiatan. Evaluasi merupakan fungsi monitoring dan penilaian terhadap proses pelatihan, apakah pelatihan ini sudah cukup efektif dan efisien dalam pelaksanaannya (Harding, Kadiyono, Hidayat, \& Yanuarti, 2018). Evaluasi dilakukan dengan cara memberikan kuesioner kepada seluruh peserta, setelah pelatihan selesai. Adapun hasil analisis kuesioner dari peserta pelatihan dapat dilihat pada Tabel 3 . 
Tabel 3. Hasil Evaluasi Kegiatan Pengabdian kepada Masyarakat

\begin{tabular}{cccccc}
\hline No. & Materi Pelatihan & STS & TS & S & SS \\
\hline 1 & $\begin{array}{c}\text { Kegiatan PKM yang } \\
\text { dilakukan memberikan solusi } \\
\text { atas masalah yang dihadapi } \\
\text { mitra }\end{array}$ & $0(0 \%)$ & $0(0 \%)$ & $4(50 \%)$ & $4(50 \%)$ \\
\hline 2 & $\begin{array}{c}\text { Anggota tim yang terlibat } \\
\text { dalam Kegiatan PKM aktif } \\
\text { dalam memberikan bantuan }\end{array}$ & $0(0 \%)$ & $0(0 \%)$ & $3(37 \%)$ & $5(63 \%)$ \\
\hline 3 & $\begin{array}{c}\text { Terjadi penambahan } \\
\text { pengetahuan dan } \\
\text { keterampilan pada mitra }\end{array}$ & $0(0 \%)$ & $0(0 \%)$ & $4(50 \%)$ & $4(50 \%)$ \\
\hline 4 & $\begin{array}{c}\text { Secara keseluruhan mitra } \\
\text { merasa puas atas kegiatan } \\
\text { PKM yang telah dilakukan }\end{array}$ & $0(0 \%)$ & $0(0 \%)$ & $2(25 \%)$ & $6(75 \%)$ \\
& & & & \\
\hline
\end{tabular}

Hasil kuesioner menyatakan bahwa sejumlah 50\% perserta menyatakan sangat setuju bahwa kegiatan PkM memberikan solusi atas masalah mitra, sedangkan sisanya $50 \%$ menyatakan setuju. Sejumlah $63 \%$ peserta menyatakan sangat setuju atas keterlibatan tim PKM yang aktif dalam memberikan bantuan selama kegiatan PKM, sedangkan 37\% menyatakan setuju. Terdapat $50 \%$ peserta yang menyatakan sangat setuju bahwa terjadi penambahan pengetahuan dan keterampilan peserta, sedangkan sisanya 50\% menyatakan setuju. Sejumlah 75\% peserta menyatakan sangat setuju, 25\% menyatakan setuju bahwa merasa puas atas kegiatan PKM yang telah dilakukan.

\section{KESIMPULAN}

Pelaksanaan pelatihan di PT. Barus Indah berjalan sesuai dengan harapan. Walaupun tingkat kehadiran hanya $72 \%$, tapi sudah bisa mewakili jumlah peserta keseluruhan. Banyaknya pertanyaan saat pelatihan menunjukkan bahwa peserta mampu memahami materi pelatihan customer service maupun positioning produk.

Dampak dari kegiatan pengabdian kepada masyarakat ini adalah PT. Barus Indah lebih memahami berbagai cara yang dapat dilakukan untuk dapat bersaing dengan perusahaan sejenis dan memenangkan hati pelanggan. Rekomendasi untuk kegiatan pengabdian kepada masyarakat selanjutnya adalah dengan fokus pada aspek digital, khususnya dalam hal pemasarannya. Mengingat tuntutan zaman yang sudah serba digital. 


\section{UCAPAN TERIMA KASIH}

Ucapan terima kasih ditujukan kepada Manajemen PT. Barus Indah dan LPPM Universitas Harapan Medan atas dukungan yang diberikan selama kegiatan pengabdian masyarakat berlangsung.

\section{DAFTAR PUSTAKA}

Butar-butar, A. K. (2018). Pengaruh Strategi Positioning terhadap Keputusan Pembelian Produk Jasa Asuransi pada PT. JIWASRAYA di Tangerang. Jurnal Manajemen Bisnis. Vol. 7. No. 1. Hal 57-64.

http://jurnal.umt.ac.id/index.php/jmb/article/viewFile/1569/1009

Harding, D., Kadiyono, A. L., Hidayat, Y., \& Yanuarti, N. (2018). Pelatihan dan Pengembangan SDM Sebagai Salah Satu Upaya Menjawab Tantangan MEA. JPSP: Jurnal Psikologi Sains dan Profesi, 185-192.

Mauliansyah, R. (2017). Pengaruh Positioning terhadap Keputusan Pembelian Sepeda Motor Honda di Kota Langsa. Jurnal Manajemen dan Keuangan. Vol. 6. No. 2. https://ejurnalunsam.id/index.php/jmk/article/view/687

Lupiyoadi, R. (2001). Manajemen Pemasaran Jasa, Salemba Empat, Jakarta.

Kotler, P., \& Keller, K. L. (2012). Manajemen Pemasaran. Jilid I. Edisi 12. Jakarta : Erlangga.

Tjiptono, F., \& Chandra, G. (2016). Service, Quality \& Satisfaction. Edisi 4. Yogyakarta : Andi.

Widjaya, P. G. (2017). Analisis Segmenting, Targeting, Positioning dan Marketing Mix pada PT. Murni Jaya. AGORA. Vol. 5. No. 1.

https://media.neliti.com/media/publications/54479-ID-analisis-segmenting-targetingpositionin.pdf

(C) 2021 by authors. Content on this article is licensed under a Creative Commons Attribution 4.0 International license. (http://creativecommons.org/licenses/by/4.0/). 